\title{
Is epithelial cell abnormality in cervical samples along with E6/7 mRNA expression of human Papilloma virus is correlated with socioeconomic status
}

\author{
Authors \\ Dr Khushboo Likhar, Prof. Dr C.V. Kulkarni, Dr Ankesh Kumar Jain, \\ Prof. Dr Meena Mittal, Prof. Dr Ashok Panchonia, Dr Priya Jain* \\ *Corresponding Author \\ Dr Priya Jain \\ Email: 35priyameenajain.5@gmail.com
}

\section{Introduction}

Cervical cancer ranked second among most commonly diagnosed cancer and in less developed countries it is third leading cause of cancer related death among females ${ }^{1,2,3}$ Cancer cervix is a multifactorial disease. Major risk factors are $\operatorname{age}^{4,5}$, illiteracy, low socioeconomic status, early menarche, marital status, early marriage, early first childbirth, age at last child birth, multiparity, abortion, multiple sexual partners, late menopause, genital infection, poor genital hygiene, tobacco use, passive smoking and contraceptive use $\mathrm{u}^{6-10}$. Other risk factors includes co-infection with Chlamydia trachomatis, non-use of condoms by partners and nutritional factors. ${ }^{11-16}$ Human Papilloma virus (HPV) infection is the most important risk factor. ${ }^{17}$ It has been shown recently that cervical cancer is strongly associated with the presence of high risk or oncogenic Human Papilloma virus (HPV) types (up to $100 \%) .{ }^{18,19}$ it is the expression of viral oncogenes E6 /E7 which is prerequisite for progression toward malignancy and maintenance of the cancerous phenotype ${ }^{20,21}$. As the severity of the lesion increases levels of E6/E7 also rises. ${ }^{22,23}$ E6 and E7 transcripts could be useful as markers of disease progression. ${ }^{22}$

\section{Aims and Objectives}

This study is carried out to correlate impact of socioeconomic status on occurrence of epithelial cell abnormality reported on cervical Pap smear study using 2014 Bethesda System and flow cytometry detection of HPV mRNA expression in present scenario.

\section{Materials and Methods}

This study was conducted in Department of Pathology, Mahatma Gandhi Medical College and Maharaja Yeshwant Rao Hospital, Indore, Madhya Pradesh, India. It is a prospective study. The study duration was one year from July 2017 to June 2018 Sample size for the study was of 40 cases.

For all patients, different socioeconomic variables like level of income, level of education, parity and awareness about risk factors were noted. For this study purpose, level of income was divided in low, middle and high based on income, 5000,/per month, 5000-30,0000 per month and $>30,000$ /per 
month respectively. Education level was divided in to illiterate and literate based on whether patient has received any formal education or not. All 40 selected women were examined per vaginally and by speculum after acquiring a detailed history and verbal consent from them. The woman was placed in dorsal lithotomy position. After proper positioning of the woman, cervix was viewed by introducing Sims' vaginal speculum and anterior vaginal retractor and external os was identified. Pap smears were made by introducing cervical brush/ cytobrush with a detachable head were inserted into the external os and rotating it through 360 degrees 8-10 times in clockwise direction near the squamo- columnar junction. The cellular material thus obtained was quickly, but gently smeared on a clean glass slide. The glass slide was then immediately put into the Coplin jar containing 95\% ethanol which acted as a fixative. The prepared smears were then stained according to Papanicolaou's technique.

The white head of the cervical brush was detached and put into the Sure Path preservative vial .Vial was then shaken well and stored at room temperature till the samples were processed for the run in flow cytometer.

\section{Results}

All 40 Pap smears studied as per the Bethesda system 2014 for reporting of cervical Pap smears. Age specific analysis of data revealed $72.5 \% \%$ (29/40) were from 21-40 yrs age. Abnormalities Negative for intraepithelial lesion or Malignancy (NILM) was reported in $62.5 \%$ (25/40) smears. $37.5 \%(15 / 40)$ showed various epithelial abnormalities including ASCUS, ASC-H, Low grade Squamous Intraepithelial Lesion (LSIL) and High Grade Intraepithelial lesion (HSIL) and squamous cell carcinoma.
Table 1 Distribution of cases on Socio-economic status

\begin{tabular}{|c|c|c|}
\hline Socioeconomic variable & $\begin{array}{l}\text { Cases show } \\
\text { epithelial cell } \\
\text { abnormality } \\
(\mathrm{n}=15)\end{array}$ & $\begin{array}{c}\text { Cases show } \\
\text { HPV mRNA } \\
\text { expression } \\
(\mathrm{n}=20)\end{array}$ \\
\hline \multicolumn{3}{|l|}{ Place of residence } \\
\hline 1. $\quad$ Rural & 10 & 17 \\
\hline 2. Urban & 05 & 03 \\
\hline \multicolumn{3}{|l|}{ Income } \\
\hline 1. Low & 09 & 13 \\
\hline 2. Middle & 05 & 05 \\
\hline 3. High & 01 & 02 \\
\hline \multicolumn{3}{|l|}{ Parity } \\
\hline 1. Nulliparous & 0 & 01 \\
\hline 2. $\quad$ Parity $<2$ & 0 & 02 \\
\hline 3. $\quad$ Parity $>2$ & 15 & 17 \\
\hline \multicolumn{3}{|l|}{ Level of education } \\
\hline 1. Illiterate & 09 & 13 \\
\hline 2. $\quad$ Literate & 06 & 07 \\
\hline
\end{tabular}

\section{Discussion}

In our study, maximum number of cases were seen in 21-40 years of age. In various other studies done by Sunita et $\mathrm{al}^{24}$ Mandakani et $\mathrm{al}^{25}$ and $\mathrm{P}$ Vijaya Lakshmi et al, ${ }^{26}$ the maximum age of patients was 31-50 years of age and correlated with progressive rise in incidence of dysplasia and carcinoma with increasing age.

In our study, $100 \%$ of abnormal smears and $85 \%$ of HPV mRNA expression were from women with more than 2 children. Misra et $\mathrm{al}^{27}$ and Goes et $\mathrm{al}^{28}$ also reported progressive rise in incidence of cervical cancer with increased parity. Multiparity causes repeated cervical trauma causing squamous metaplastic changes which is a strong risk factor for development of cervical cancer. Another possible mechanism is increased endogenous estrogen production during repeated pregnancy causing persistence of HPV infection by synergizing the effect of HPV oncoproteins and down-regulating cell mediated immune response progressing to dysplasia and carcinoma. In our study, majority of the patients with epithelial cell abnormality $60 \%$ and $65 \%$ cases with HPV mRNA expression were from low income category. Poverty has a cascading effect on their lives leading to malnourishment, poor hygiene and sanitation, low immunity, low female literacy and poor access to healthcare facility. 
Studies conducted by Misra et $\mathrm{al}^{27}$ and Zhang et $\mathrm{al}^{29}$ and showed strong association between poor genital hygiene and cervical carcinoma.

According to one study, 17 there is $100 \%$ increase in incidence of cervical cancer and $60 \%$ increase in incidence of dysplasia and carcinoma in situ. Other studies that have found a preponderance of HPV in low socioeconomic groups ${ }^{30-32}$.

\section{Conclusion}

Increasing incidence of cervical dysplasia and invasive cervical cancer can be prevented by spreading awareness about various socioeconomic and etiological contributory factors. All these factors causes development of dysplasia and progression to cervical cancer. In our study, cases with rural background with Low income, high parity and illiterate had higher number of abnormal smears along with high positive expression of HPV mRNA E6/7 which is most important risk factor for cervical carcinogenesis. This stresses the need for more social awareness specific to cervical cancer, literacy, provision of safe and adequate water for hygiene and effective family planning. Stressing the need for Improvement in these factors, especially in rural areas can go a long way in reducing burden of cervical cancer in developing countries.

\section{References}

1. Lindsey A. Torre; Freddie Bray; Rebecca L. Siegel; Jacques Ferlay; JoannieLortetTieulent; AhmedinJemal. Global Cancer Statistics, 2012. CA CANCER J CLIN 2015;65:87-108: 99-100.

2. Bojgua S; Kldiashvili E. Liquid Based Cytology Cervical Cancer Screening Program - Georgian Experience. Arch Can Res. 2016, 4: 3.

3. Ekane, G.E.H et al. (2015) Pap smear Screening, the Way Forward for Prevention of Cervical Cancer? A Community Based Study in the Buea Health District, Cameroon. Open Journal of Obstetrics and Gynecology, 5, 226-233.
4. Sánchez-Anguiano LF, Alvarado-Esquivel C, Reyes-Romero MA, Carrera- Rodríguez M. Human papilloma virus infections in women seeking cervical Papanicolaou cytology of Durango, Mexico: Prevalence and genotype. BMC Infec Dis 2006;6:2733.

5. García-Piñeres AJ, Hildesheim A, Herrero R, Trivett M, Williams M, Atmetlla I, et al. Persistent human papillomavirus infection is associated with a generalized decrease in immune responsiveness in older women. Cancer Res 2006;66:110706.

6. Patil V, Wahab SN, Zodpey S, Vasudeo ND. Development and validation of risk scoring system for prediction of cancer cervix. Indian J Public Health 2006;50:3842.

7. Juneja A, Sehgal A, Mitra AB, Pandey A. A survey on risk factors associated with cervical cancer. Indian J Cancer. 2003 JanMar;40:15-22.

8. Mukherjee BN, Sengupta S, Chaudhuri S, Biswas LN, Maiti P.A. case-control study of reproductive risk factors associated with cervical cancer. Int J Cancer. 1994 Nov 15;59:476-82.

9. Gawande V, Wahab SN, Zodpey SP, Vasudeo ND. Risk factors for cancer cervix: a case control study. Indian J Cancer. 1998;35:164-70.

10. Aparajita Dasgupta, Narendra N Naskar, Rama Ram, Sila Deb A. Community Based Study On The Prevalence Of Risk Factors OF Cancer Cervix In Married Women Of A Rural Area Of West Bengal Year. Indian journal of community medicine 2002;27:35-38.

11. International Collaboration of Epidemiological Studies of Cervical Cancer, Appleby P, Beral V, Berrington de González A, Colin D, Franceschi S, Goodhill A, et al. Cervical cancer and hormonal contraceptives: collaborative 
reanalysis of individual data on 16,573 women with cervical cancer and 35,509 women without cervical cancer from 24 epidemiological studies. Lancet 2007;370:1609-21.

12. Smith JS, Bosetti C, Munoz N, Herrero R, Bosch FX, Eluf-Neto J, et al. IARC Multicentric Cervical Cancer Study Group. Chlamydia trachomatis and invasive cervical cancer: A pooled analysis of the IARC multicentric case-control study. Int J Cancer 2004;111:431-9.

13. Richardson H, Abrahamowicz M, Tellier PP, Kelsall G, du Berger R, Ferenczy A, et al. Modifiable risk factors associated with clearance of type-specific cervical human papillomavirus infections in a cohort of university students. Cancer Epidemiol Biomarkers Prev 2005;14: 1149-56.

14. Lai CH, Chao A, Chang CJ, Chao FY, Huang HJ, Hsueh S, et al. Host and viral factors in relation to clearance of human papillomavirus infection: a cohort study in Taiwan. Int J Cancer 2008;123:1685-92.

15. Tortolero-Luna G. Epidemiology of genital human papillomavirus. Hematol Oncol Clin North Am 1999;13:245-57.

16. Kjaer SK, Chackerian B, van den Brule AJ, Svare EI, Paull G, Walbomers JM, et al. High-risk human papillomavirus is sexually transmitted: Evidence from a follow-up study of virgins starting sexual activity (intercourse). Cancer Epidemiol Biomarkers Prev 2001;10:101- 6.

17. Schiffman M, Castle PE, Jeronim J, Rodrigue AC, Wacholde S. Human papillomavirus and cervical cancer.Lancet. 2007;370:890-

907. [PubMed]

18. Van den Brule AJC, Walboomers JMM, du Maine M, Kenemans P, Meijer CJLM. Difference in prevalence of human papillomavirus genotypes in cytomorphologically normal cervical smears is associated with a history of cervical intraepithelial neoplasia. Int $\mathbf{J}$ Cancer 1991;48: 404-8.

19. Resnick RM, Comelissen MTE, Wright DK, Eichinger GH, Fox HS, ter Schegget $\mathrm{J}$, et al. Detection and typing of human papilloma virus in archival cervical cancer specimens by DNA amplification with consensus primers. J Natl Cancer Inst 1990;82:1477-84.

20. Fehrmann F, Laimins LA. Human papillomaviruses targeting differentiating epithelial cells for malignant transformation. Oncogene 2003;22:5201 7.

21. Boulet G, Horvath C, Vanden Broeck D, et al. Human papillomavirus:E6 and E7 oncogenes. Int $\mathrm{J}$ Biochem Cell Biol 2007;39:2006 - 11 .

22. Cattani P, Zannoni GF, Ricci C, et al. Clinical performance of human papillomavirus E6 and E7 mRNA testing for high-grade lesions of the cervix. J ClinMicrobiol 2009;47(12):3895-3901

23. Argyri E, Tsimplaki E, Daskalopoulou D, et al. E6/E7 mRNA expression of high-risk HPV types in 849 Greek women. Anticancer Res 2013;33(9):4007-4011

24. Bamanikar Sunita A., Baravkar Daaso S., Chandanwala Shirish S., Papkikar Prachet. Study of Cervical Pap smears in a Tertiary Hospital. Indian Medical Gazette 2014:250-54.

25. Patel Mandakini M, Pandya Amrish N, Modi Jigna. Cervical Pap Smear Study and its utility in Cancer Screening, to specify the strategy for cervical cancer control. National Journal of Community Medicine 2011;2.

26. Vijaya Lakshmi P., Sree Gouri S.R. Study and Analysis of Two Hundred Cervical PAP Smears in Our Hospital. International Journal of Contemporary Medical Research 2016;3:2787-9.

27. Mishra JS, Srivastava S, Singh U, Srivastava AN. Risk factors and strategies 
for control of Carcinoma Cervix: Hospital based cytological screening experience of 35 years. Indian Journal of Cancer 2009;46(2).

28. Goes JJS, Goes JC, Lemos LB, Dias JC, Donoso NF, Zyngier SB et al. Practical approaches to screening for cervical cancer. Cancer Detect Prev 1987; 10:26577

29. Zhang ZF, Parkin DM, Yusz. Risk factors for cancer of cervix in a rural Chinese population. Int J Cancer. 1989;43:762-7.

30. Bauer HM, Hildesheim A, Schiffman MH, et al. Determinants of genital human papillomavirus infection in low-risk women in Portland, Oregon. Sex Transm Dis. 1993;20:274- 278.

31. Hildesheim A, Gravitt P, Schiffman MH, et al. Determinants of genital human papillomavirus infection in low-income women in Washington, DC. Sex Transm Dis. 1993;20:279- 285.

32. Wheeler CM, Parmenter CA, Hunt WC, et al. Determinants of genital human papillomavirus infection among cytologically normal women attending the University of New Mexico student health center. Sex Transm Dis. 1993;20:286-289. 